\title{
O POTRZEBIE WIEDZY HUMANISTYCZNEJ. KU WYCHOWANIU CZŁOWIEKA ZINTEGROWANEGO. PRÓBA WSKAZANIA TROPÓW
}

\begin{abstract}
Aвstract. Joachimowska Magdalena, O potrzebie wiedzy humanistycznej. Ku wychowaniu człowieka zintegrowanego. Próba wskazania tropów [On the Need for Humanistic Knowledge. Striving for an Integrated Person. An Attempt at New Leads]. Studia Edukacyjne nr 58, 2020, Poznań 2020, pp. 283-299. Adam Mickiewicz University Press. ISSN 1233-6688. DOI: 10.14746/se.2020.58.20

The content of the article was created during the search for justification for, stated in the subject literature, the need for the existence of an integrated (trans-disciplinary) science about humans; this need to gather existing knowledge which allows for a comprehensive and holistic understanding about an individual, their essence (both humans and their humanity) and their activity encouraging the education of a person ready to take responsibility for the quality of their life resulting from reflection and understanding. Bringing up self-aware and thinking people, who realize themselves in their personal, professional and social life, who are responsible for themselves, others, and the world around them. The aim of the conducted analysis was also to search for a common language (common categories and meanings) of researchers from various scientific fields (philosophy, anthropology, sociology, pedagogy, physics, law, history, mathematics and others) and various cultures concerned about their existence, and thus about the existence of an individual and their humanity.
\end{abstract}

Key words: humanistic education, classical culture, knowledge about humans, thinking (humanistic thinking), understanding

\section{Wprowadzenie. Idea zrozumienia w jednym, wspólnym świecie}

Przyjęte w tytule określenie wychowania człowieka zintegrowanego nawiązuje do przedstawionej we wcześniejszym artykule koncepcji wychowania humanistycznego ${ }^{1}$ i obejmuje integrację $\mathrm{w}$ wymiarze indywidualnym oraz

${ }^{1}$ Zob. M. Joachimowska, O potrzebie wychowania humanistycznego. Wybrane kategorie $i$ ich znaczenie dla rozwoju indywidualnego i społecznego, Edukacja, 2019, 2. 
społecznym, przeciwdziałającą zdiagnozowanym w literaturze przedmiotu takim problemom, jak: zagubienie, wykluczenie, osamotnienie, zewnątrzsterowalność, czy niemoc współczesnego człowieka. Człowiek zintegrowany rozumiany jest tutaj jako zdolny wytyczać i kreować swoje życie, zarządzać własnym losem $\mathrm{w}$ poczuciu zgody ze sobą i w dobrych relacjach $\mathrm{z}$ innymi. Człowiek dobrze funkcjonujący w świecie natury i kultury, mający kontrolę nad tym co tworzy, szczególnie w kwestii gospodarki i technologii, ponoszący odpowiedzialność za swoje wytwory.

Jednym z najczęściej powtarzających się motywów w przeprowadzonych badaniach jest, choć różnie formułowane (ubierane w słowa), jednak mające wspólny sens, przekonanie, iż w istocie jest ,jeden" człowiek i ,jeden” świat, wszyscy ludzie mają wspólną istotę człowieczeństwa i wspólny świat do dyspozycji. Przekonanie to ma moc zobowiązującą do podejmowania w tej kwestii działań uświadamiających, aktywizujących do myślenia, motywujących do zaangażowania oraz wynikających z nich działań wychowawczych. Jak zostało ujęte $\mathrm{w}$ tytule, poniższe rozważania są próbą wskazania pewnych tropów z różnorakich dziedzin i dyscyplin naukowych dla pedagogiki, a zwłaszcza wychowania humanistycznego w duchu kultury klasycznej, którego fundamentami są zrozumienie człowieczeństwa, świata oraz odpowiedzialności za podejmowane aktywności/działania człowieka w świecie poprzez refleksję i zrozumienie.

W przeprowadzonych analizach zostały odczytane dwa wzajemnie powiązane procesy. Jeden z nich oscyluje wokół konieczności ujmowania świata jako całości, który przyjmuje różne odsłony, ale również wiele wspólnych znaczeń ${ }^{2}$. Drugi proces koncentruje się wokół podkreślanej potrzeby jedności antropologii człowieka, ujmowanego „poza kulturą" (z wyjątkiem tezy Nisbeta), opartej na tym co wspólne człowiekowi, a nie co go różni od innych ${ }^{3}$. Obydwa procesy zaznaczają pewną, określoną (różnie przez wymienionych badaczy) jedność czy całość człowieka i świata oraz wskazują na ich zbliżony sens i pojmowanie. $W$ pierwszym mamy do czynienia z jednością i cało-

${ }^{2}$ I tak, dla Edgara Morina jest to proces mondializacji warunkujący wspólnotę losu człowieka i Ziemi, dla Hansa-Georga Gadamera - jednolita cywilizacja powszechna, dla Jana Patoćki - dzieje planetarne, dla Fichtego - powszechny związek ludzkości, dla Petera Singera - jedno społeczeństwo światowe, dla Barbera - epoka współzależności w wymiarze globalnym, a dla Norberta Eliasa - narastająca współzależność jednostek.

3 Tutaj można wymienić: noologię Edgara Morina, propozycję antropologii filozoficznej Chantal Delsol, konieczność studiowania człowieka - Blaise'a Pascala, teorię człowieka ... Mariana Nowaka, znajomość siebie wynikającą z wiedzy o człowieku Edwarda T. Halla (wyjaśnia kulturowe uwarunkowania), głębokie myślenie Tadeusza Gadacza, atrybuty człowieczeństwa Margaret Archer i wizję człowieka Władysława Lorenca oraz tezę o uwarunkowaniach myślenia człowieka Roberta Nisbetta. Chociaż ta ostatnia wskazuje na różnice właśnie, to nie wyklucza wspólnoty człowieczeństwa wszystkich kultur, a zrozumienie/przyjęcie przedstawianej tezy pozwala na uniknięcie nieporozumień. 
ścią w wymiarze społecznym, relacyjnym, natomiast $\mathrm{w}$ drugim z jednością i całością w wymiarze indywidualnym, jednostkowym, które oczywiście się warunkują. Jednak jak już zostało powiedziane, celem było odnalezienie wspólnych znaczeń, a nie korelacja między nimi. Wyodrębniony podział jest oczywiście sztuczny, przywołany na potrzeby analiz, gdyż historia człowieka i świata jest wspólna.

Zatem, badając teksty, w celu ustalenia pewnych wspólnych kategorii ${ }^{4}$ i ich znaczeń istotnych w wychowaniu humanistycznym, można zauważyć (czy często? - to już kwestia miary) sygnalizowaną propozycję utworzenia nowej nauki - ponaddyscyplinarnej czy interdyscyplinarnej - o człowieku, uwzględniającej dorobek różnorodnych dziedzin i dyscyplin naukowych wnoszących wiedzę o człowieku i jego aktywności w świecie. Propozycja ta przez niektórych twórców wiedzy humanistycznej jest uważana za niemożliwą do zrealizowania. Jednak zapewne warto poznać argumenty tych, którzy brak takiej nauki dostrzegają i postulują jej utworzenie jako platformy wymiany myśli o człowieku i jego świecie, ułatwiającej jego zrozumienie, przekładające się na odpowiedzialne działania w życiu osobistym i społecznym.

\section{Nowa, ponad/dyscyplinarna nauka o człowieku i jego dziejach - tropy jednej drogi}

Hans-Georg Gadamer wyznacza ludzkości pewne zadanie, a mianowicie stwierdza, iż:

Jest tylko jeden świat. Ziemia zamieszkana jest przez jedną ludzkość. Narodów jest wiele, języków jest wiele. A nauka? Czy nauka jest jedna? (...) czy dotyczy to także nauki o człowieku? ${ }^{5}$

W swych rozważaniach stawia zasadnicze pytania. Czy uświadamiając sobie, że

ludzkość łączy się coraz bardziej w jednolitą cywilizację powszechną, której dzieje splatają się w jeden jedyny los ludzki na tej ziemi, nie powinniśmy, podążając za Heraklitem, i pozwolić, by przemówił wspólny nam wszystkim rozum? Czy nie powinniśmy spróbować rozmowy, która nas wszystkich łączy? Rozmowy różnie ukształtowanych ludzi, których łączą wspólne przekonania i wartości ${ }^{6}$. To co inne i odmienne - czytamy w zakończeniu - może stać się też okazją do spotkania z samym sobą. Pilniejszym niż kiedykolwiek zadaniem jest nauczyć się rozpoznawać w innym i w inno-

\footnotetext{
${ }^{4}$ Kategorie te zostały zaprezentowane w przywołanym w poprzednim przypisie artykule.

${ }^{5}$ H-G. Gadamer, Stowo na drogę i Obywatele dwóch światów, [w:] Człowiek w nauce współczesnej. Rozmowy w Castel Gandolfo, red. K. Michalski, Kraków 2006, s. 9.

${ }^{6}$ Tamże, s. 9-10.
} 
ści to, co wspólne. (...) Natomiast nauka o człowieku w całej jego różnorodności staje się etycznym i filozoficznym zadaniem dla nas wszystkich ${ }^{7}$,

zadaniem poszukiwania wspólnego w inności.

Edgar Morin, jak można odczytać, proponuje noologię jako nową naukę o człowieku ${ }^{8}$ oraz kategorię mondializacji (uświatowienia), która uzasadnia potrzebę nauki o jednym świecie i jego przemianach. Los ludzki i los Ziemi stanowią ścisły związek, który implikuje wspólnotę losu. „Ziemia jest złożoną całością fizyczno-biologiczno-antropologiczną (...) [a] wspólnota losu ludzkości musi się wpisać we wspólnotę losu ziemskiego" ${ }^{\prime 9}$. Filozof odnajduje przyczynę bezsilności współczesnego człowieka w braku wiedzy humanistycznej. Ponieważ niewsparta wiedzą humanistyczną wiedza techniczna stanowi dzisiaj właśnie istotę i motor agonii planetarnej, w której tkwi największy problem, jakim jest „bezsilność świata pragnącego stać się światem i bezsilność ludzkości pragnącej stać się ludzkością"10. Wskazany brak wiedzy humanistycznej jest przyczyną niedorozwoju rozwiniętych społeczeństw, który rośnie wraz z ich rozwojem techniczno-ekonomicznym. Wynika stąd, stawiany przez myśliciela, postulat potrzeby (za)istnienia kultury planetarnej, która ma dwa podstawowe cele: zachowawczy i rewolucjonizujący. Pierwszy polega na zachowaniu i ochronie różnorodności kulturowych i przyrodniczych, drugi dotyczy stworzenia warunków, w których ludzkość znalazłaby swoje spełnienie jako wspólnota narodów, społeczność planetarna. Drugi cel jest możliwy do zrealizowania pod warunkiem zrewolucjonizowania relacji międzyludzkich we wszystkich możliwych sferach - to jest stosunek do samego siebie, do innych ludzi i innych narodów oraz kultur, włącznie z ich wiedzą, przyrodą i techniką.

Mamy bowiem do czynienia z mondializacją komunikacji, wymiany czy też poczucia planetarnego obywatelstwa, które umożliwiają łączenie się ludzi w poszanowaniu odrębności kultur; mamy też mondializację zmierzającą do ujednolicenia i zmechanizowania, zmierzającą do zniszczenia skarbu, jakim dla ludzkości jest jej własna różnorodność ${ }^{11}$.

Ta podwójna, dualistyczna mondializacja wskazuje na konieczność uwolnienia się od schematów w myśleniu i działaniu, co można osiągnąć jedynie poprzez ich przemyślenie i zrozumienie $\mathrm{w}$ kontekście własnych przekonań i zachowań. Takie ujęcie stanowi kolejny głos, w sugerowanej przez Gada-

\footnotetext{
7 Tamże, s. 202.

${ }^{8}$ E. Morin, A.B. Kern, Ziemia - ojczyzna, Warszawa 1998, s. 271-273.

9 Tamże, s. 80-81.

10 Tamże, s. 131.

11 Tamże, s. 8-9.
} 
mera rozmowie, która poprzez zrozumienie będzie łączyć a nie dzielić ludzi, kultury, świat.

W kwestii jedności antropologicznej człowieka cytowany autor przekonuje, iż jest ona niepodważalna i nazywa ją jednorodnością wieloraką (unitas multiplex), która jest zasadą tożsamości ludzkiej ${ }^{12}$. Według Morina, wszelkie specjalizacje są zgubne, a to że nie mamy scalonej wiedzy antropologicznej nie jest dziełem przypadku. Remedium na brak jej skorelowanego scalenia, jakie postuluje, jest myślenie kompleksowe w miejsce myślenia redukcyjnego, kaleczącego, cząstkowego, upraszczającego, mechanicznego, katalogującego, abstrahującego. Jego zarzut wobec filozofii dotyczy, między innymi, braku powiązań subiektywnych doświadczeń badanych przez na przykład egzystencjalistów z wiedzą antropologiczną.

Zdecydowanym zwolennikiem syntetyzowania wiedzy o człowieku i jego dziejach jest Jan Patočka, który zauważa dwa kolidujące ze sobą procesy. Jego zdaniem, po II wojnie światowej dzieje nie są już dziejami Europy, lecz dziejami planetarnymi, a mimo to ludzka troska odeszła od spraw duchowych ku sprawom zewnętrznym - na przykład posiadaniu czy panowa$\mathrm{niu}^{13}$. Filozof ten podkreśla istotę $\mathrm{i}$ znaczenie wiedzy historycznej w rozwoju człowieka, określając go jako istotę dziejową. Istotę żyjącą, niestety, w dwóch oderwanych od siebie światach (naturalnym i naukowym), która utraciła umiejętność myślenia o bycie jako całości, co pozbawiło ją duchowej siły. Ponadto,

w wyniku rewolucji naukowej metafizykę zniewoliły siły ekonomiczne, polityczne, naukowe i religijne, a homo spirutuale zastąpił homo faber oraz homo historicus, (...) natomiast nauki podzieliły między siebie całą rzeczywistość i nie są zdolne uchwycić już całości świata jako jedności uniwersum, lecz wyłącznie jako zbiór faktów ${ }^{14}$.

Inne efekty zamiany metafizyki w system nauk szczegółowych, według praskiego filozofa, to wyobcowanie nauki z życia przeżywanego, oddzielenie nauki od filozofii, zamiana prawdy faktami i ich manipulowaniem, unikanie subiektywności, skończoności i niepewności.

Patočka wskazuje również na istotny związek dziejów pojedynczego człowieka i dziejów świata, gdzie współzależność ludzkiej aktywności z dziejami to podstawa autentycznego bycia (v. Heidegger). Dzieje stanowią „śswiadome kształtowanie życia człowieka, które nieustannie odnosi się do całości świata" a "filozofia dziejów to pytanie o sens bycia człowieka w świecie"15. W zakon-

12 Tamże, s. 72-75.

${ }^{13}$ D. Bęben, Człowiek w horyzoncie dziejów i autentyczności bycia. Studia z filozofii Jana Patočki, Katowice 2016, s. 86-87.

14 Por. tamże, s. 25.

15 Tamże, s. 56-58. 
czeniu studiów z filozofii człowieka czeskiego myśliciela autor podsumowuje je znaczącymi słowami' iż:

Jedna z ważniejszych kwestii, do których można sprowadzić omawiane tu problemy, to wychowanie, rozumiane w greckim kontekście jako paideia, która nie poddaje się naukowym schematom ${ }^{16}$.

Kolejna zwolenniczka prezentowanej idei/potrzeby, Chantal Delsol, proponuje teorię ujmującą człowieka „poza kulturą” (v. E.T. Hall), w ramach antropologii filozoficznej wskazującej cechy naszego gatunku, a nie antropologii kulturowej przedstawiającej cechy człowieka w określonej kulturze, wychwytującej cechy wspólne całej ludzkości (w zachowaniu w różnych sferach życia), które ją łączą a nie dzielą, aby bariery zastąpić mostami ${ }^{17}$. Jak sama to ujmuje: „(..) antropologia filozoficzna wychodzi z założenia, że gatunek ludzki jest j e d e n i że głębokie różnice kulturowe nie przeważają nad tą jednością" ${ }^{18}$. Jako uzasadnienie prezentuje fundamentalne cechy wskazujące na stałość człowieka mimo jego nieustannej ewolucji i zdolności do samoprzekształcania. Zdaniem Delsol, człowiek nie staje się ucywilizowany przez kształcenie intelektualne, lecz przez kształtowanie wrażliwości i wewnętrzny rozwój, poprzez poznawanie oraz rozwijanie siebie i swojego człowieczeństwa, poprzez zdobywanie wiedzy o człowieku i świadomemu jej odnoszeniu do siebie, do swoich życiowych aktywności. Natomiast,

szczytowym osiągnięciem cywilizacji jest subtelny i mało widoczny, w porównaniu z rozwojem naukowym [technologicznym - M.J.], rozwój człowieka, kiedy w społeczeństwie pojawia się wysoki poziom świadomości, troska o prawdę połączoną z tolerancją [a jeszcze lepiej z akceptacją - M.J.], troska o dobro zaprawione wyrozumiałością dla osób, wierność sobie, zgodność między myślami i czynami, co wszyscy uznają za godny naśladowania model człowieczeństwa ${ }^{19}$.

Natomiast Johann G. Fichte już na przełomie XVIII i XIX wieku prognozuje mondializację (choć oczywiście nie używa tego terminu) jako wspólną drogę, jako związek powszechny całej ludzkości. Gdyż jak czytamy:

Przeznaczeniem naszego rodu jest zespolenie się w jedność, w ciało we wszystkich swych częściach ze sobą najzupełniej zaznajomione i we wszystkim jednakowo rozwinięte. Przyroda, nawet namiętności i błędy ludzkie dążyły od początku ku temu celowi. Już wielka część drogi została pokonana i liczyć można z pewnością na to, że

16 Tamże, s. 201.

17 Ch. Delsol, Czym jest człowiek? Kurs antropologii dla niewtajemniczonych, przekł. M. Kowalska, Kraków 2011, s. 10-11.

18 Tamże, s. 12.

19 Tamże, s. 137. 
cel ten, warunek dalszych wspólnych postępów, uzyskany zostanie w swoim czasie. (...) Zanim jednak ród nasz stanie się zdolny do nieograniczonego stykania się z sobą, każdy naród musi czekać na drugi, każda część świata czekać musi na drugą ${ }^{20}$.

Wiele lat później Norbert Elias w Społeczeństwie jednostek również podkreśla i potwierdza nasilenie współzależności jednostek oraz wskazuje iż:

Zrozumienie jednostki (jej działań) jest możliwe tylko w kategoriach jej wspólnotowego życia z innymi, ponieważ struktura i ukształtowanie kontroli zachowania jednostki zależą od struktury relacji między indywiduami ${ }^{21}$.

Podobnie ujmują tę kwestię Christakis i Towler, używając terminologii sieci społecznych.

Blaise Pascal w kwestii nauki o człowieku podkreśla, iż trzeba znać samego siebie, lecz i ubolewa, że niewielu ludzi w ogóle chce zajmować się kwestią/problematyką człowieka, co kilka wieków później powtarza, z niemniejszym rozgoryczeniem i troską o uzupełnienie braków w tejże wiedzy przywołana już Ch. Delsol. Dla pełnego zobrazowania rozczarowania Pascala przytaczam szeroki fragment z jego Myśli:

Spędziłem długi czas na zgłębianiu nauk oderwanych, ale zbyt mała okazja do wymiany myśli zmierziła mnie. Kiedy zabrałem się do studiowania człowieka, przekonałem się, że te nauki oderwane nie są dlań stworzone i że dalej odszedłem od mej kondycji wnikając w nie, niż inni - nie znając ich. Przebaczyłem innym ich nieznajomość, ale sądziłem bodaj, iż znajdę wielu towarzyszy w studiowaniu człowieka, i że to jest jemu przyrodzona wiedza. Omyliłem się, jeszcze mniej ludzi studiuje tę wiedzę niż matematykę (...). Trzeba znać samego siebie: gdyby to nie posłużyło do znalezienia prawdy, służy przynajmniej do wytyczenia własnego życia, a nie ma nic godziwszego. Nie uczy się ludzi, jak być porządnymi ludźmi, a uczy się ich wszystkiego innego; im zaś nigdy nie zależy tyle na reszcie, co na tym, aby być ludźmi. Zależy im wyłącznie na znajomości jedynej rzeczy, której się nie ucząa2 .

Tymi słowami M. Nowak w Podstawach pedagogiki otwartej uzasadnia konieczność ufundowania pedagogiki na teorii człowieka ${ }^{23}$. Wychowanie natomiast definiuje jako urzeczywistnianie człowieczeństwa w człowieku, którego podstawy ontologiczne, aksjologiczne i antropologiczne stanowią zręby pedagogiki otwartej. Określa on również warunek sine qua non dla tworzenia koncepcji wychowania, mianowicie:

${ }^{20}$ J.G. Fichte, Powołanie człowieka, przekł. A. Zieleńczyk, Kęty 2002, s. 85.

${ }^{21}$ N. Elias, Społeczeństwo jednostek, przekł. J. Stawiński, Warszawa 2008, s. 77.

22 B. Pascal, Myśli, Warszawa 1997, s. 50.

${ }_{23}$ M. Nowak, Podstawy pedagogiki otwartej. Ujęcie dynamiczne w inspiracji chrześcijańskiej, Lublin 1999, s. 295. 
Droga do rozumienia i rozpoznania człowieka oraz zauważenia istotnych wartości jego istnienia prowadzi poprzez poszukiwanie odpowiedzi na podstawowe pytanie: kim/czym jest człowiek? Dopiero wtedy można postawić kolejne pytania jakiego człowieka wychowywać, jak wychowywać, aby mógł on uczynić swoje życie naprawdę ludzkim ${ }^{24}$.

Pewną odpowiedź i wyjaśnienie potrzeby wiedzy o człowieku, w świecie naznaczonym dysproporcją rozwoju technologii i humanistyki, warte zacytowania podaje w wywiadzie dla „Polityki” Tadeusz Gadacz:

Bo po kilku tysiącach lat systematycznego myślenia już bardzo dużo wiemy o naszej kondycji, ludzkim losie, ludzkich ograniczeniach, emocjach, reakcjach. Kiedyś ten intelektualny dorobek pomagał ludziom w życiu. Dziś został odrzucony. Technologiczna logika zniszczyła nawyk i umiejętność głębokiego myślenia, które nas czyni ludzkimi. A rezygnując z głębszego myślenia człowiek stał się bezradny wobec własnej, ludzkiej rzeczywistości. Coraz lepiej rozumiemy i kontrolujemy materię, a coraz gorzej siebie. To jest fundamentalny brak, który odczuwamy. (...) Nie wiemy, co robimy, bo nie rozumiemy, co mówimy. A nie możemy rozumieć tego, co mówimy, póki nie wiemy, co myślimy, póki nie podejmiemy głębszego namysłu, który jest niemożliwy bez przygotowania ${ }^{25}$.

Również Peter Singer wskazuje na ów brak kontroli nad własnym losem charakteryzujący współczesnego człowieka. W swojej etyce globalizacji, zawartej w publikacji Jeden świat. Etyka globalizacji, pisze o nadchodzącej erze jednego społeczeństwa światowego oraz przedstawia diagnozy i wynikające z nich postulaty dla ludzkości. „Problemem globalizacji jest przede wszystkim to, że nikt nie rządzi, a ludzkość zamiast rządzić własnym losem, poddaje się władzy własnego wytworu, czyli globalnej gospodarce" ${ }^{26}$. W kwestii wychowania i edukacji potrzeba uświadomienia tej prawdy jest kluczowa dla pytania, jak poradzimy sobie, jako ludzkość, w czasach globalizacji? Zdaniem Singera, odpowiedź zależy „od naszej etycznej reakcji na ideę jednego świata" ${ }^{27}$. W związku z tym zadaniem wychowawczym jest uczenie respektowania innych istot ludzkich niezależnie od rasy, religii i polityki oraz tego, że etyka jest uwarunkowana kulturowo ${ }^{28}$.

Dużo wcześniej Edward T. Hall w swych dociekaniach badawczych określa potrzebę kontroli tworzonych technologii w opisywanym przezeń braku panowania nad materią. Według niego, człowiek oddzielił się od siebie samego i nie jest już zdolny kontrolować potworów, które sam stworzył, co odczytuje jako skutki dysproporcji między technologią a naturą i humanistyką

\footnotetext{
${ }^{24}$ Tamże, s. 227-229.

${ }^{25}$ T. Gadacz, Nędza humanistyki. Nie ma szczęścia bez myślenia, „Polityka”, 2005, 12 grudnia.

${ }^{26}$ P. Singer, Jeden świat. Etyka globalizacji, przekł. C. Cieślikowski, Warszawa 2006, s. 33.

27 Tamże, s. 34-35.

${ }^{28}$ Zob. tamże, s. 154-156.
} 
na rzecz tej pierwszej. „Człowiek prawie nigdy nie boi się o siebie, być może dlatego, że tak mało wie o sobie samym i nie ma niczego, z czym mógłby się porównać" ${ }^{29}$, powinien zatem rozszerzać i pogłębiać wiedzę na temat swojego nieprawdopodobnego organizmu/jestestwa oraz aktywnie i świadomie angażować się w życie społeczne. W dziele z 1976 roku o wymownym tytule Poza kulturą można odczytać kolejną tezę zawartą w słowach:

Przyszłość ludzkości zależy od tego, czy człowiek przekroczy granice poszczególnych kultur, aby było to możliwe musi nauczyć się rozróżniać liczne ukryte wymiary pozawerbalnych aspektów życia, które warunkują nasze postrzeganie świata i ludzi ${ }^{30}$.

Treści jego analiz i diagnoz dotyczą dwóch kryzysów relacji człowieka, z kulturą i z naturą, ze szczególnym uwzględnieniem stosunku do samego siebie (świadomość, samorefleksja), do swoich ekstensji, instytucji, idei oraz relacji z innymi ludźmi, grupami społecznymi w wymiarze globalnym.

Richard E. Nisbett wskazuje na kolejny zdiagnozowany czynnik. Mianowicie, stwierdza, iż charakter ludzkiego myślenia nie jest uniwersalny, co jest podstawowym założeniem w opracowaniu zawartym w Geografii myślenia, dla którego autor przytacza liczne argumenty poparte pracami badawczymi z dziedziny nauk społecznych i humanistycznych. Zdaniem uczonego, zrozumienie różnic daje możliwości poprawy stosunków międzyludzkich na świecie, w szczególności zaś między Wschodem i Zachodem ${ }^{31}$. W edukacji i wychowaniu niezbędne są zatem odpowiedzi na pytania: Jakie są przyczyny ludzkich zachowań? Jakie są sposoby myślenia? Jak ludzie dokonują wyborów? Jak dokonywać trafnych kategoryzacji świata? Jaki wpływ na myślenie ma sytuacja/kontekst? Jakie schematy i stereotypy kierują naszym życiem? Jak istotne są sformułowania wypowiedzi? Jaką mamy świadomość wpływu społecznego? Czy nasze przekonania są zgodne z prawdą? ${ }^{32}$

W kwestii współzależności i zarazem lepszej kontroli nad gospodarką, technologiami i działaniami społecznymi ekonomista Beniamin R. Barber proponuje stworzenie światowego demokratycznego parlamentu globalnego, który stanowić będą burmistrzowie i radni miast oraz regionów metropolitalnych. W uzasadnieniu podaje, iż miasta wytwarzają 80\% PKB świata i są zamieszkiwane przez ponad połowę ludzkości. Sugeruje, aby globalne problemy rozwiązywali oni tak, jak na co dzień rozwiązują problemy lokalne, gdyż państwowe instytucje, postrzegane przez autora jako przestarzałe, nie radzą sobie z nimi. Tak znaczące instytucje, jak terytorialne państwo, sądy,

${ }^{29}$ E.T. Hall, Ukryty wymiar, Warszawa 2001, s. 13.

${ }^{30}$ Tamże, s. 10.

${ }^{31}$ R.E. Nisbett, Geografia myślenia. Dlaczego ludzie Wschodu i Zachodu myśla inaczej, przekł. E. Wojtych, Sopot 2009, s. 15.

${ }^{32}$ Zob. R.E. Nisbett, Mindware. Narzędzia skutecznego myślenia, Sopot 2016. 
kościoły, armie są bezradne wobec współczesnych problemów, gdyż: „epokę niezależności zamieniła epoka współzależności" ${ }^{33}$. Wskazuje on również, podobnie jak Morin, na fakt, iż gatunek ludzki ma problemy z odczuwaniem wspólnoty globalnej.

\section{Współpraca międzydyscyplinarna - tropy drugiej drogi}

Nieodzowność współpracy wyspecjalizowanych dyscyplin i subdyscyplin naukowych wydaje się oczywista, jednak w wymiarze praktycznym przejawia wiele braków, zarówno w systemach edukacji, jak i na poziomie wymiany naukowej. Jednym z przykładów jest zdecydowana przewaga konferencji naukowych zrzeszających badaczy jednej dyscypliny, a tym samym brak konferencji łączących dyscypliny humanistyczne i nauki ścisłe.

Już w latach 80. XX wieku J. Bańka proponował w kwestii teorii człowieka budowanie cywilizacji eutyfronicznej - jako ideału cywilizacji - zmierzającej do harmonizowania pierwiastka tymicznego i fronicznego w procesie dziejowym, gdzie eutyfronika postuluje uzupełnienie racjonalności techniki przez wartościującą prostomyślność nauk humanistycznych. Proponuje on zatem etykę prostomyślności, która, zgodnie z dyrektywą J. Fourastié, wskazuje na konieczność łączenia instynktu i logiki, które mogą jednocześnie sprzyjać postępowi techniki oraz chronić człowieka przed nieprzewidzianymi skutkami rozwoju cywilizacji.

Dokonując wyboru, nie powinieneś zawieszać praw instynktu i logiki pólintuicyjnej, ponieważ jest to z jednej strony niemożliwe, z drugiej prowadzi do decyzji-wyboru, która może pociągnąć za sobą zniszczenie jednostki i gatunku $u^{34}$.

Zgodnie z prognozą Tofflera o wkroczeniu (świata?) w trzecią fazę rewolucji naukowej, którą jest rewolucja humanistyczna, autor wskazuje, iż

kultura środowisk technicznych winna tworzyć harmonijną całość, nie zaś zlepek powierzchownie scalonych elementów techniki i humanistyki ${ }^{35}$.

W kwestii wychowania współczesnego człowieka stawia następującą tezę:

Sztuka życia wewnętrznego, świadome organizowanie nastrojów i wszystko co składa się na postawę psychiczną podmiotowego ",ja" jednostki - to sprawy syntezy filozofii, psychologii, socjologii, antropologii i etyki, do której osiągnięcia trzeba by aktualnie

33 B.R. Barber, Świat miast, „Polityka”, 2014, 43 (2981)/2014-10-22, s. 35.

${ }^{34}$ J. Bańka, Ja teraz. U źródeł filozofii człowieka wspótczesnego, Katowice 1983, s. 229.

${ }^{35}$ Tamże, s. 379. 
zmierzać, aby odpowiedzieć sobie i innym nie tyle na abstrakcyjne pytanie: Kim jestem $j a$ ?, jak to czyni personalizm, ale przede wszystkim na konkretne pytanie człowieka prostomyślnego: Kim jestem ja teraz? ${ }^{36}$

Jedna z wnikliwych badaczek współczesnej kondycji człowieka Martha C. Nussbaum pisze szeroko o modelu klasycznej edukacji humanistycznej (obok modelu edukacji nakierowanej na wzrost gospodarczy) w kontekście demokracji, a konkretnie - możliwości jej rozwoju. Zwraca uwagę na funkcjonujący w większości amerykańskich uniwersytetów paradygmat sztuk wyzwolonych (który w Europie zanikł niestety całkowicie), którego esencją jest nauczanie przez pierwsze dwa lata studiów zobowiązujące studentów do wyboru szerokiej gamy kursów humanistycznych zamiast pojedynczych przedmiotów, co rzutuje również na nauczanie na poziomie średnim i chroni młodych ludzi przed „zbyt wczesnym zmuszaniem do wejścia na tory niehumanistyczne" ${ }^{37}$. Kolejnym aspektem edukacji humanistycznej, wyróżnionym przez autorkę, jest nacisk na aktywność dziecka w procesie zdobywania wiedzy.

Nauka nie polega na biernym przyswajaniu faktów oraz tradycji kulturowych, ale raczej na stymulowaniu aktywności umysłu i zwiększaniu jego kompetencji oraz rozwijaniu rozumnego krytycyzmu wobec złożonego świata, który nas otacza ${ }^{38}$.

Również w twórczości Michela Maffesoliego wybrzmiewa teza, iż aby zrozumieć rzeczywistość współczesności, należy wykorzystać klasyków i zgodnie z myślą starożytną nie dzielić wiedzy o człowieku na specjalizacje. A skoro one już są i funkcjonują, niestety szeroko, we współczesnym poszufladkowanym świecie, niezbędna jest ich współpraca w wymianie myśli i wspólnych projektach. Także Wacław Makarczyk w dziele Wspólnota uczuć i działań wskazuje na liczne powiązania socjologii, psychologii i biologii z antropologią w kontekście zrozumienia działania człowieka, a w szczególności jego społecznego zaangażowania. Wiktor i Iwona Werner w kwestii współpracy interdyscyplinarnej konkludują, że: „złożoność zjawiska, jakim jest człowiek, wymyka się wszelkim jednorodnym metodologiom badawczym i podziałom na dyscypliny naukowe" ${ }^{39}$, gdyż jak czytamy w uzasadnieniu: fundament każdej integralnej refleksji o człowieku ma charakter interdyscyplinarny. Niestety „we współczesnych naukach o człowieku dbałość o czy-

${ }^{36}$ Tamże, s. 16.

${ }^{37}$ M. Nussbaum, Nie dla zysku. Dlaczego demokracja potrzebuje humanistów, Warszawa 2016, s. $33-34$

38 Tamże, s. 34.

${ }^{39}$ W. Werner, I. Werner, Od duszy do świadomości. Od jednostki do społeczeństwa, Poznań 2008, s. 7. 
stość metodologiczną ze środka stała się celem, a zaawansowanie metod nie przekłada się na doniosłość twierdzeń końcowych" ${ }^{\prime 4}$.

Wobec powyższego, wydaje się oczywiste, że ku lepszemu zrozumieniu człowieka i jego aktywności niezbędna staje się współpraca wielu dziedzin i dyscyplin naukowych (jak np. historii, psychologii, socjologii, pedagogiki, etyki, estetyki, filozofii, biologii, neurologii, genetyki i in.), mająca przyczyniać się zarówno do rozwoju w wymiarze indywidualnym, jak i społecznym. Współpraca dająca podstawy wychowania refleksyjnych i zintegrowanych osób mających namysł nad swoim sprawstwem w swym odpowiedzialnym zaangażowaniu. Jednym z wymiarów takiej, służącej wszechstronnemu rozwojowi człowieka i ludzkości, współpracy powinny być naukowe konferencje interdyscyplinarne.

\section{Praktyczny wymiar współpracy międzydyscyplinarnej}

Jednym z obiecujących przykładów dotyczących tworzenia międzydyscyplinarnej wiedzy o człowieku jest działalność Instytutu Nauk o Człowieku w siedzibą w Wiedniu (od 1982 roku), podjęta z inicjatywy grupy polskich i niemieckich filozofów, historyków i socjologów współpracujących przede wszystkim w ramach Interuniversity Center w Dubrowniku. Jednym z zasadniczych celów wiedeńskiego instytutu jest lepsze zrozumienie się wzajemne pochodzących z różnych kultur naukowców, artystów i intelektualistów, istotne dla nich samych oraz zwłaszcza dla rezultatów naukowych ${ }^{41}$. Bowiem jak słusznie stwierdza Krzysztof Michalski:

Nauka - jak i inne rodzaje pracy intelektualnej - sensowna jest tylko w jakimś określonym kontekście kulturowym, w kontekście wspólnoty porozumiewających się ze sobą ludzi (...), szczególnie zaś w naukach o człowieku².

Zatem, chodzi o udział w dyskusjach przekraczających granice naukowych dyscyplin, konkretnych doświadczeń społecznych i historycznych, gdzie rozpoznanie lokalnych problemów pozwoli uchwycić ich znaczenie uniwersalne oraz umożliwi wypracowanie argumentów służących zmianie przekonań, na te służące całej ludzkości. Aby uniknąć oczywistości, o której pisał Ferdynand Braudel, iż: „Każdą naukę społeczną cechuje imperializm,

40 Tamże, s. 34.

41 Zob. K. Michalski (red.), Człowiek w nauce wspótczesnej. Rozmowy w Castel Gandolfo, Kraków 2006, s. 5-6.

42 Tamże, s. 6. 
nawet gdy się przed tym broni, każda dąży do przedstawienia swoich konkluzji jako globalnej wizji człowieka"43. Jak celnie zauważa Gieysztor:

trzeba ograniczyć nasze pytania i zastanowić się, jaka nauka historyczna wydaje się dziś najbardziej otwarta, aby z niej współczesna i jutrzejsza humanistyka mogła czerpać składniki syntezy antropologicznej, albo skromniej - takiej antropologii, która nie zaniedbałaby uwzględnić bardzo długiej obecności człowieka na Ziemi ${ }^{44}$.

Warto zaznaczyć istotę oraz rolę przekonań w budowaniu/tworzeniu światopoglądu i wiedzy o człowieku oraz świecie, ale jest to temat wymagający odrębnego opracowania w kwestii wychowania humanistycznego i jego niezbędnych/nieuniknionych kategorii.

\section{Podsumowanie. \\ Pedagogika jako nauka (scalająca wiedzę) o człowieku i jego życiu (?) - sugerowany trop}

Związek wychowania - a poprzez jego przypisanie do pedagogiki i jej samej (pedagogiki) - z wieloma innymi naukami wydaje się oczywisty. Na tym między innymi polega problem naukowości pedagogiki związany z jej miejscem w nauce oraz rolą, jaką pełni w wychowawczej rzeczywistości społecznej. Włodzimierz Lorenc stwierdza, iż pojęcie humanizmu powstało na gruncie pedagogiki i pierwotnie odnosiło się do kwestii kształcenia w duchu kultury klasycznej, która nota bene jest we współczesnej edukacji nieobecna ${ }^{45}$.

Pedagogika - jak pisze M. Nowak - to zespół nauk o wychowaniu i nie sposób jej uprawiać bez wiedzy ontologicznej (potrzeba odniesienia się do rzeczywistości wychowawczej), aksjologicznej (wartości i wynikające z nich cele wychowania), antropologicznej (koncepcja człowieka), które absolutnie nie mogą być od siebie oderwane. Zatem, wskazana już wcześniej przez autora prawidłowa kolejność w kształtowaniu koncepcji/teorii oraz wynikających z nich (lub odwrotnie) działań pedagogicznych jest taka: najpierw pytamy kim jest człowiek, a jako drugie stawiamy pytanie, jak może on zaktualizować swoje życie, aby było ono naprawdę ludzkie ${ }^{46}$ - czyli od koncepcji człowieka do koncepcji wychowania.

Naukowość pedagogiki, a właściwie problem z uznaniem jej naukowości wynika między innymi ze względu na przynależność wychowania do

${ }^{43}$ F. Braudel, za: A. Gieysztor, Człowiek w perspektywie nauk historycznych, [w:] Tamże, s. 65.

${ }^{44}$ Tamże, s. 74.

${ }^{45}$ W. Lorenc, W poszukiwaniu filozofii humanistycznej, Warszawa 1998, s. 6.

${ }^{46}$ M. Nowak, Podstawy pedagogiki otwartej. Ujęcie dynamiczne w inspiracji chrześcijańskiej, Lublin 1999, s. 228-229. 
różnych sfer rzeczywistości ludzkiej - od biologicznej, psychologicznej, społecznej i historycznej, aż po filozoficzną i teologiczną ${ }^{47}$. Istota pedagogiki jako nauki zajmującej się procesem wychowania i tym wszystkim co się z nim łączy, czyli: naturą, kulturą, społeczeństwem, duchem, uczuciami i emocjami, celami i tym podobne, jest bardzo złożona i skomplikowana. Autor określa pedagogikę jako naukę praktyczną, a ściślej prakseologiczną wśród humanistycznych ${ }^{48}$, związaną z natury z otwartym działaniem, gdyż wychowanie jest zawsze uwarunkowane historycznie i łączy się z całą rzeczywistością społeczno-kulturalno-przyrodniczą. Natomiast, Wilhelm Flitner mówi o pedagogice jako nauce hermeneutyczno-pragmatycznej ${ }^{49}$. Jednak - co z kolei zauważa Theodor Dietrich - pomimo silnego związku pedagogiki z różnymi grupami nauk jest ona przede wszystkim nauką antropologiczną ${ }^{50}$, a w swej złożoności określa ją jako filozoficzno-humanistyczną, przyrodniczą i prakseologiczną ${ }^{51}$. Interdyscyplinarność jest więc w pedagogikę wpisana ze względu na jej podmiot jak i przedmiot, zatem dlaczego studia pedagogiczne są tak okrojone z wielu wyżej wymienionych dziedzin i dyscyplin.

Może to właśnie pedagogika mogłaby być nauką jednoczącą wiedzę o człowieku i jego aktywności w świecie wraz z jej praktyką, a raczej sztuką wychowania wykraczającą daleko poza instytucje oświatowo-wychowawcze. Pytanie pozostawiam otwarte, jak też otwarta powinna być pedagogika. Powrót do wychowania humanistycznego bazującego na klasyce zasadza się między innymi na cnotach. Sprawności intelektu i woli, czyli cnoty istotne $\mathrm{w}$ wychowaniu są zawarte między innymi w realistycznych koncepcjach człowieka, takich jak: antropologiczne podstawy wychowania Tomasza z Akwinu, pedagogika realistyczna (pedagogika esse) M. Gogacza, czy pedagogika aretologiczna J. Woronieckiego. Kolejne fundamenty - w odczytanych tekstach - to powrót do paidei i metanoi, jako celnych metod wychowawczych, sprzyjających wszechstronnemu rozwojowi i integrowaniu człowieka.

Przeprowadzone analizy wskazują, iż jednym z zasadniczych argumentów zaistniałej potrzeby zebrania i uporządkowania wiedzy o człowieku jest dający się zauważyć wyraźny proces mondializacji, z towarzyszącą mu globalizacją i bałkanizacją, i coraz większą, ściślejszą współzależnością ludzi całego globu ziemskiego. Drugi argument wynika z kolei z konieczności zrozumienia człowieka i jego zachowań, czyli zrozumienia siebie, innych oraz tworzonego przez nas - ludzi świata, zjawisk i procesów w nim zachodzących. Rozumienie skutków i przyczyn podejmowanych decyzji, które, jak się

\footnotetext{
47 Tamże, s. 175.

48 Tamże, s. 174.

49 W. Flitner 1957, za: tamże, s. 201.

50 Tamże, s. 225.

51 M. Dietrich 1990, za: tamże, s. 579.
} 
okazuje, wymagają zintegrowanej wiedzy o człowieku i świecie oraz zintegrowania jego samego w procesie wychowania są, między innymi, pochodną zdolności samodzielnego myślenia oraz samodzielnego i zespołowego działania. Jak zatem wychować człowieka zintegrowanego? Jedną z właściwych dróg wydaje się zintegrowanie wiedzy na temat człowieka. Wiedzy o człowieku, jego naturze, kulturze, jego aktywnościach oraz motywacjach kierujących jego wyborami. Wiedzy, którą można przekuć w integrujące koncepcje wychowania.

Przedstawione w zarysie propozycje różnych myślicieli i naukowców, żyjących głównie w XX wieku (poza Pascalem - XVII w. i Fichtem - XVIII i XIX w.), zbiegają się jak w soczewce w konieczności powrotu do klasyków starożytnych, a zwłaszcza koncepcji wychowania i związanej z nim przemiany, czyli do paidei i metanoi, gdzie celem podejmowanych działan wychowawczych jest myślenie (w tym analiza przekonań), rozumienie i zrozumienie, zamiast „przerabiania”, urabiania, czy zmieniania człowieka. Aby, parafrazując słowa znakomitego polskiego filozofa Stefana Świeżawskiego,

wychować człowieka, który myśli i zastanawia się nad rzeczywistością, w której został postawiony, dziwi się przy głębszej refleksji nie tylko temu wszystkiemu, co go otacza, ale nade wszystko samemu sobie - istocie nieznanej ${ }^{52}$.

Wychowanie w duchu paidei i metanoi wydaje się antidotum na zdiagnozowany przez wielu przytaczanych myślicieli i naukowców brak refleksji, brak rozumienia, brak poszukiwań, brak stawiania pytań sobie i innym. Może przyczynić się do podniesienia poziomu refleksji na temat życia człowieka i jego celów. Odpowiedzi na pytania, kim jest człowiek, czym jest człowiek mamy w dorobku naukowym wiele, jednak ile one wnoszą do lepszego kierowania swoim życiem w działaniach człowieka? Kierowania w duchu metanoi, czyli zmiany sposobu myślenia i postępowania i związanych z nimi wyborów nakierowanych na prawdę, dobro, czyli mądrość. Tak rozumiana metanoia jest przecież czynnikiem utrwalającym humanizm, chroniącym osoby i ich relacje.

Humanizacja kultury winna dotyczyć również procesu humanizacji wychowania. O konieczności humanizacji kultury piszą szeroko między innymi M. Gogacz w Etyce chronienia osób i K. Wojtyła o integracji osoby w czynie (Osoba i czyn). Sugerowana natomiast humanizacja wychowania ujmuje człowieka całościowo, co przejawia się w kształtowaniu charakteru, intelektu, woli, uczuć i sumienia ${ }^{53}$.

${ }^{52}$ Św. Tomasz z Akwinu, Traktat o człowieku. Summa teologiczna, oprac. S. Świeżawski, Poznań 1956, s. V.

${ }^{53}$ Por. M. Krasnodębski, Człowiek i paideia. Realistyczne podstawy filozofii wychowania, Warszawa 2009, s. 367. 
Zamykając krótki przegląd wybranych tropów różnych autorów argumentujących tytułową potrzebę zintegrowania wiedzy humanistycznej, warto przytoczyć, zawarte między pesymizmem a optymizmem, znamienne słowa S. Świeżawskiego:

Myśl nowożytna musiała przejść wiele tragicznych, ale jakże pouczających dróg prowadzących na manowce i na smutne pustynie, by się wreszcie przekonać, że jednak filozofia nie może pomijać człowieka, a w człowieku nie powinna się ograniczać do samej tylko refleksji nad jego poznawaniem. Jesteśmy niewątpliwie świadkami powolnego renesansu filozoficznej teorii człowieka ${ }^{54}$.

\section{BIBLIOGRAFIA}

Barber B.R., Świat miast, „Polityka”, 2014, 43 (2981)/2014-10-22.

Bańka J., Ja teraz. U źródeł filozofii człowieka wspótczesnego, Wydawnictwo Śląsk, Katowice 1983.

Bęben D., Człowiek w horyzoncie dziejów i autentyczności bycia. Studia z filozofii Jana Patočki, Wydawnictwo Uniwersytetu Śląskiego, Katowice 2016.

Bloom A., Szekspir i polityka, Wydawnictwo Arcana, Kraków1995.

Delsol Ch., Czym jest człowiek? Kurs antropologii dla niewtajemniczonych, przekł. M. Kowalska, Instytut Wydawniczy Znak, Kraków 2011.

Elias N., Społeczeństwo jednostek, przekł. J. Stawiński, Wydawnictwo Naukowe PWN, Warszawa 2008.

Fichte J.G., Powołanie człowieka, przekł. A. Zieleńczyk, Wydawnictwo Antyk, Kęty 2002.

Gadacz T., Nędza humanistyki. Nie ma szczęścia bez myślenia, „Polityka”, 2005, 12 grudnia.

Gadamer H-G., Stowo na drogę i Obywatele dwóch światów, [w:] Człowiek w nauce wspótczesnej. Rozmowy w Castel Gandolfo, red. K. Michalski, Instytut Wydawniczy Znak, Kraków 2006.

Gieysztor A., Człowiek w perspektywie nauk historycznych, [w:] Człowiek w nauce wspótczesnej. Rozmowy w Castel Gandolfo, red. K. Michalski, Instytut Wydawniczy Znak, Kraków 2006.

Hall E.T., Ukryty wymiar, Wydawnictwo Muza, Warszawa 2001.

Joachimowska M., O potrzebie wychowania humanistycznego. Wybrane kategorie $i$ ich znaczenie dla rozwoju indywidualnego i społecznego, Edukacja, 2019, 149, 2.

Krasnodębski M., Człowiek i paideia. Realistyczne podstawy filozofii wychowania, Wydawnictwo SWPR, Warszawa 2009.

Lorenc W., W poszukiwaniu filozofii humanistycznej, Wydawnictwo Naukowe Scholar, Warszawa 1998.

Lorenc W., Hermeneutyczne koncepcje człowieka w kręgu inspiracji heideggerowskich, Wydawnictwo Naukowe Scholar, Warszawa 2003.

Maffesoli M., Czas plemion. Schyłek indywidualizmu w społeczeństwach ponowoczesnych, Wydawnictwo Naukowe PWN, Warszawa 2008.

Makarczyk W., Wspólnota uczuć i działań, IFiS PAN, Warszawa 1993.

${ }^{54}$ S. Świeżawski oprac., Św. Tomasz z Akwinu, Traktat o człowieku, s. VIII. 
Michalski K. (red.), Człowiek w nauce współczesnej. Rozmowy w Castel Gandolfo, Instytut Wydawniczy Znak, Kraków 2006.

Morin E., Zagubiony paradygmat - natura ludzka, Państwowy Instytut Wydawniczy, Warszawa 1977.

Morin E., Kern A.B., Ziemia - ojczyzna, Państwowy Instytut Wydawniczy, Warszawa 1998.

Nisbett R.E., Geografia myślenia. Dlaczego ludzie Wschodu i Zachodu myśla inaczej, przekł. E. Wojtych, Wydawnictwo Smak Słowa, Sopot 2009.

Nisbett R.E., Mindware. Narzędzia skutecznego myślenia, Wydawnictwo Smak Słowa, Sopot 2016.

Nowak M., Podstawy pedagogiki otwartej. Ujęcie dynamiczne w inspiracji chrześcijańskiej, Wydawnictwo KUL, Lublin 1999.

Nussbaum M., Nie dla zysku. Dlaczego demokracja potrzebuje humanistów, Fundacja Kultura Liberalna, Warszawa 2016.

Pascal B., Myśli, Instytut Wydawniczy „Pax”, Warszawa 1997.

Savater F., Proste pytania, Wydawnictwo Universitas, Kraków 2000.

Singer P., Jeden świat. Etyka globalizacji, przekł. C. Cieślikowski, Książka i Wiedza, Warszawa 2006.

Św. Tomasz z Akwinu, Traktat o człowieku. Summa teologiczna, oprac. S. Świeżawski, Pallottinum, Poznań 1956.

Werner W., Werner I., Od duszy do świadomości. Od jednostki do społeczeństwa, Wydawnictwo Naukowe UAM, Poznań 2008. 